\title{
Benthic community-mediated sediment dynamics
}

\author{
F. Montserrat ${ }^{1,2, *}$, C. Van Colen ${ }^{3}$, S. Degraer ${ }^{3,4}$, T. Ysebaert ${ }^{2}$, P. M. J. Herman ${ }^{2}$ \\ ${ }^{1}$ Delft University of Technology, Faculty of Civil engineering and Geosciences, Hydraulics Section, PO Box 5048, \\ 2600 GA Delft, The Netherlands \\ ${ }^{2}$ Netherlands Institute of Ecology, Centre for Estuarine and Marine Ecology, Korringaweg 7, 4401 NT Yerseke, \\ The Netherlands \\ ${ }^{3}$ Ghent University, Marine Biology Department, Krijgslaan 281/S8, 9000 Ghent, Belgium \\ ${ }^{4}$ Management Unit of the North Sea Mathematical Models, Royal Belgian Institute of Natural Sciences, Gulledelle 100, \\ 1200 Brussels, Belgium
}

\begin{abstract}
We assessed the influence of benthic communities on sediment properties in large defaunation experiments in replicated $16 \mathrm{~m}^{2}$ plots on a tidal flat in the Westerschelde estuary (SW Netherlands). We compared microphytobenthos and benthic macrofauna recovery and recolonisation between control and defaunated sediments during 8 mo following the defaunation, focussing on how the temporal scale of biological responses interact with the temporal scale of sedimentological developments (grain size, bed level, erosion threshold). In the first month, microphytobenthos (surface chl a content) increased to $>3$ times the control values and remained elevated until 3 mo after the start of the experiment. Macrofaunal recovery started with mobile mudsnails after only a few days. Tube-building macrofauna dominated first, followed by surface-disrupting species. Both groups became much more dominant in defaunated than in control plots. Surface pelletisers almost recovered to control levels after $4 \mathrm{mo}$, while biodiffusing bivalves did not recover during the course of the experiment. Mud content of the sediment surface first increased with chl $a$, but started to decrease, concomitant with an over-representation of surface disruptors. A similar trend was observed for critical erosion threshold. Bed elevation of experimental plots exceeded controls by several $\mathrm{cm}$ after $1 \mathrm{mo}$, and remained higher through summer. The time scales of changes in microphytobenthos and in abiotic characteristics of the sediment were largely set by the time scale of macrofauna recovery. Macrobenthos plays a critical, but complex role in the dynamics of intertidal sediments.
\end{abstract}

KEY WORDS: Intertidal · Sediment · Erosion · Deposition · Bio-physical interactions · Macrobenthos $\cdot$ Microphytobenthos $\cdot$ Grain size

Resale or republication not permitted without written consent of the publisher

\section{INTRODUCTION}

Biogenically mediated sediment (in)stability in intertidal cohesive sediments of estuaries and coastal areas have been well studied over the past decades (Rhoads 1967, Daborn et al. 1993, Underwood \& Paterson 1993, Widdows et al. 2004). It has become increasingly clear that biotic components of the ecosystem can exert significant influence on the erosion and deposition processes in sediments (Woodin \& Jackson 1979). For example, Rhoads \& Young (1970) demonstrated that the presence of bioturbating, deposit-feeding poly- chaetes in a US East Coast tidal embayment altered sediment variables in the top layer. Widdows et al. (2000) found no significant relations between erosion and physical sediment variables (e.g. mud content, porosity), whereas those between erosion and biological variables (e.g. chl $a$ and colloidal carbon concentrations, and macrobenthic density and biomass) were highly significant.

Research on sediment-biota relationships in intertidal soft sediments recognises 2 counteracting forces: (1) the sediment cohesion-inducing and sediment surface-armouring effect of bacteria (e.g. cyanobacteria) 
and benthic microalgae (microphytobenthos; MPB), such as epipelic diatom mats (de Boer 1981, Krumbein et al. 1994, de Brouwer et al. 2000) and (2) the sediment cohesion-disrupting, destabilising or bioturbatory effects of benthic macrofauna (Rhoads \& Young 1970, Grant \& Daborn 1994, de Deckere et al. 2001, Orvain et al. 2006). The main effect of microphytobenthic aggregates is on the sediment surface strength, which results in an increase of the critical erosion threshold $\left(\tau_{\text {crit }}\right)$. Within the aggregates the cells and sediment particles alike are bound together by extracellular polymeric substances (EPS; Hoagland et al. 1993, de Brouwer et al. 2003a) and promote cohesiveness and resistance. This was demonstrated in the classical field experiment of de Boer (1981) where MPB poisoning was shown to increase erodability of the sediment.

The influences of benthic macrofauna on erodability of fine-grained and muddy sediments seem ambiguous at first glance as both stabilisation and destabilisation can be expected (Woodin \& Jackson 1979, Jumars \& Nowell 1984a, Snelgrove \& Butman 1994). Sediment characteristics can be altered in various ways, depending on the feeding mode, locomotory behaviour and sediment processing by the organism in question. Also, certain effects may be density-dependent (Eckman et al. 1981, Bolam \& Fernandes 2002, Ciutat et al. 2007). Reef-forming epifauna (e.g. oysters, mussels) protect the sediment from erosion by shielding it from the current and by modifying the turbulent benthic boundary layer responsible for erosion (van Duren et al. 2006). The suspension feeding behaviour of these organisms can have profound effects on the immediate environment. They reduce turbidity through clearance of the water column, which may promote MPB primary production. The excretion of faeces and/or pseudo-faeces is thought to have an enhancing effect on the cohesiveness of the surrounding sediment and to facilitate dispersal, deposition and even growth of resuspended MPB (Barille \& Cognie 2000, Widdows et al. 2000). Motile infauna (e.g. bivalves, crustaceans, gastropods, polychaetes) are generally considered to have a destabilising effect on the sediment surface, either directly or through grazing on MPB aggregates. (Blanchard et al. 2000, de Deckere et al. 2001, Andersen et al. 2002, Orvain et al. 2004).

In some cases, both stabilisation as well as destabilisation of the sediment by the same species has been observed. Probably the macrobenthic soft sediment species with the most diverse effects is Nereis (= Hediste) diversicolor, which displays a whole array of modes of locomotion and foraging, thereby processing the sediment in very different manners and exerting equally various influences on it, both stabilising and destabilising (Gerino \& Stora 1991, Banta et al. 1999, Palomo \& Iribarne 2000).

Estuarine sediments consist of mixtures of sand and mud (van Ledden et al. 2004, Winterwerp \& van Kesteren 2004). Mud, in turn, is composed of silt and clay and determines the cohesiveness of the sediment. Relatively small changes in composition of the sediment can cause the sediment matrix to change from a granular, sand-dominated matrix into one where the sand grains loose contact with each other and are captured in a mud-dominated matrix. The behaviour can then change abruptly from non-cohesive to cohesive or vice-versa (Winterwerp \& van Kesteren 2004), changing the erosion threshold and erosive behaviour and its dynamics. Transport models suggest that changes in erosion/deposition parameters typically caused by benthic organisms, are sufficiently large to lead to significant effects at a larger spatial scale (Paarlberg et al. 2005), but these predictions are in need of direct experimental testing.

Ecosystem engineering, as coined by Jones et al. (1994), is a prime organism-environment interaction in intertidal areas (van de Koppel et al. 2001, 2005, Bouma et al. 2005, van Wesenbeeck et al. 2007) in which organisms influence each other via autogenic or allogenic modifications of their mutual habitat on different spatial and temporal scales (Woodin 1978, Woodin \& Jackson 1979). The effects a benthic macrofaunal community can exert on its abiotic soft sediment environment are hard to distinguish, because of various naturally confounding factors. Each group of organisms uses specific traits to secure and maintain its niche within the system. Unravelling the reciprocal relationships between the dynamics of coastal sediments and their inhabitants, per species or functional group in the field, will shed light on the separate effects of each of these groups.

In this paper we present a concise set of observations on the interactions between biotic (i.e. MPB and benthic macrofauna) and abiotic (i.e. grain size distribution, bed level, erosion threshold) compartments of estuarine soft sediments obtained using a defaunation experiment in the field. Defaunation is a powerful and versatile in situ method for study of benthic macrofauna and its influences. It can be achieved by applying phylum-selective poisons (Underwood \& Paterson 1993, de Deckere et al. 2001), or by inducing severe hypoxia (Beukema et al. 1999, Norkko et al. 2006)

Field experiments offer a number of advantages compared to laboratory experiments or (unmanipulated) field observations. Unmanipulated field observations are always to a certain degree cross-system comparisons, where interference of sediment type, elevation, tidal and wave exposure etc. may influence 
biotic-abiotic relationships. Experiments with a single species or with artificial species assemblages have limited applicability to the real world. Field experiments manipulating initial conditions offer the advantage that different stages of a community can be studied while it develops according to natural regulation. Covariation of different factors reflects this natural development. The disadvantage of the approach is that results may be scale-dependent (Norkko et al. 2006) and that analysis is complicated during the course of community recovery.

Here, we aim to address 3 issues: (1) by defaunating the experimental sediment, we were able to compare the sedimentological properties of naturally inhabited and azoic sediment during approximately the first month of the experiment, thus deriving an estimate of the influence of the total benthic community; (2) a high frequency sampling of control and defaunated sediments during the 8 mo following the defaunation further enabled us to follow the macrofauna recolonisation patterns and the corresponding developments in sedimentological properties; (3) the defaunation treatment provided us with information on how the temporal scale of macrofaunal response (i.e. recolonisation) is reflected in the temporal scale of sedimentological developments.

\section{MATERIALS AND METHODS}

Site, defaunation treatment and sampling. The site chosen for the experiment was Paulinapolder, a homogeneous intertidal flat, both in terms of macrofauna composition and sedimentology, situated on the southern shore of the Westerschelde estuary at $51^{\circ} 21^{\prime} 24^{\prime \prime} \mathrm{N}$, $3^{\circ} 42^{\prime} 51^{\prime \prime} \mathrm{E}$ (Fig. 1). It is bordered by a sea defence (i.e. dike) at its back, running roughly from ENE to WSW. The prevailing winds are southwesterly and the experimental plots were shielded from them by the dike. Also, the site was largely protected from the forces of major flood currents and sea waves from the west by a breakwater barrier located ca. $50 \mathrm{~m}$ west of the plots. For further specifications of the estuary and/or the site see Herman et al. (2001), Widdows et al. (2004) and Ysebaert \& Herman (2002).

For the experiment, $16 \mathrm{~m}^{2}$ square plots were laid out at random, at least $5 \mathrm{~m}$, but no more than $35 \mathrm{~m}$, apart. We used 3 plots as controls and 3 were defaunated (i.e. treatment), by digging a $30 \mathrm{~cm}$ deep, $20 \mathrm{~cm}$ wide trench around each of them. The treated plots were covered and the trenches lined using waterproof $0.1 \mathrm{~mm}$ thick polyethylene (PE), and left to incubate. However, during the incubation, we observed small holes in the PE sheeting. We inserted an extra sheet

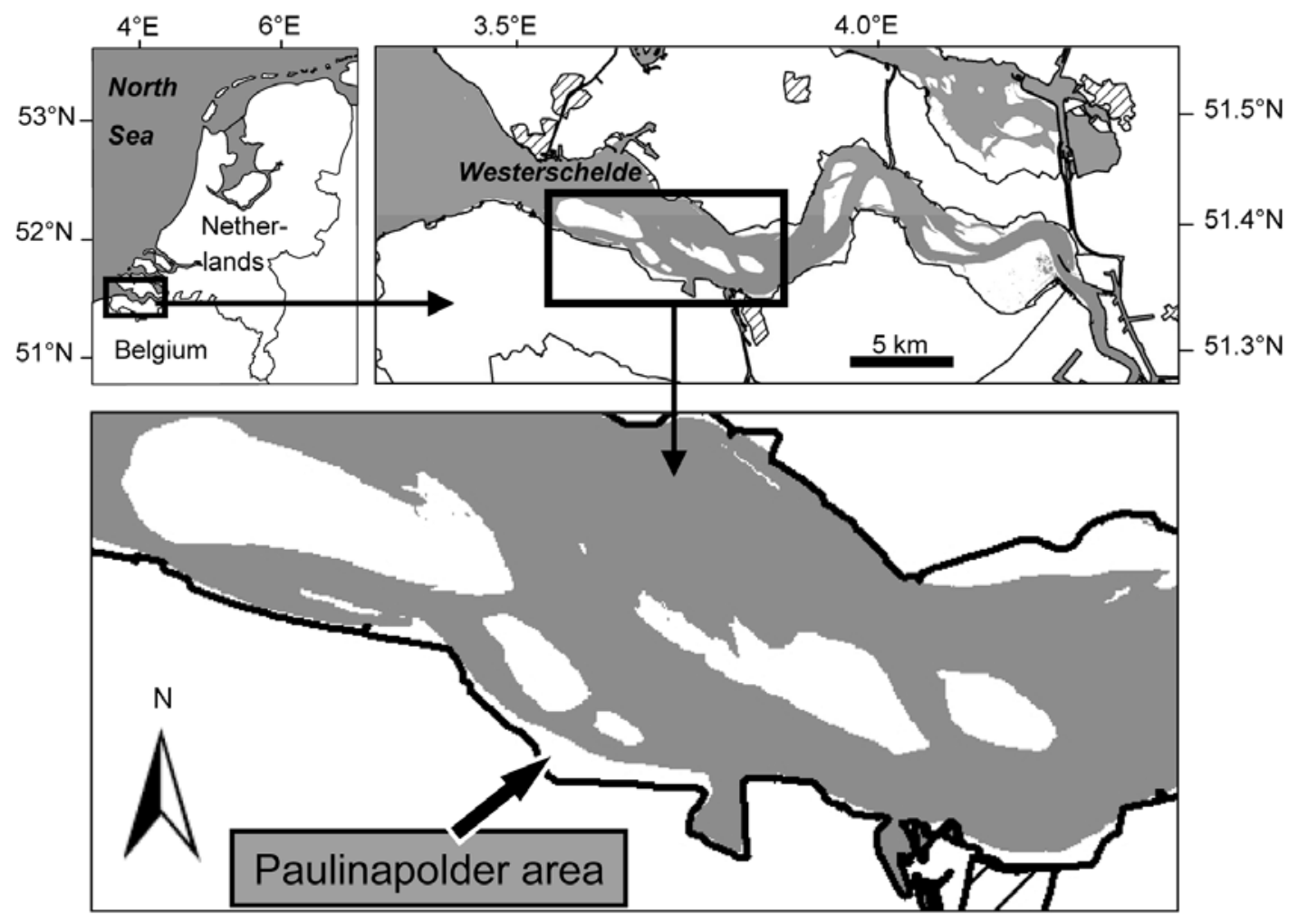

Fig. 1. Location of the intertidal area used in this study. Plots were located on the south shore, within the polyhaline part of the Westerschelde estuary 
(tarpaulin, $140 \mathrm{~g} \mathrm{~m}^{-2}$ ) in the same manner as the first to cover the treated plots. Prior to the experiment, we tested how long the period of defaunation had to last to reach azoic conditions. After 1 mo almost all macrofauna were found dead, except for some Heteromastus filiformis individuals. Other polychaete worms were found dead at the sediment surface. At this time, dead bivalves already appeared as empty shell doublets. A $40 \mathrm{~d}$ period of defaunation resulted in an azoic sediment, without even the most stress-tolerant species such as $H$. filiformis. The dead polychaetes observed after 1 mo of defaunation were absent after $40 \mathrm{~d}$, indicating decomposition of all soft organic matter within the plots. A time period of $40 \mathrm{~d}$ was thus adopted as the experimental defaunation time. At the start of the experiment, the sheets covering the plots were cut loose at the sediment surface and removed. The $30 \mathrm{~cm}$ deep lining of the trenches along the perimeter of the plots was left in place to prevent horizontal subsurface migration of infauna. By preventing this migration and relying solely on larval settlement, one is able to make general statements about larger areas affected by hypoxia and mass mortality of the macrofaunal community (i.e. upscaling). Whenever the lining emerged at the sediment surface, it was reinserted to minimise surface effects. To allow for a full recruitment and recolonisation potential of the experimental plots, the experiment was initiated (plots opened) on the 30 March 2005, which is prior to the recruitment peak of all important macrobenthic species in the area (Ysebaert 2000). After the plots were opened on Day 0, they were sampled consecutively at Days $0,1,2,7,14,21$, $28,42,56,70,84,98,112,126,140,154,175,187,203$, 233 and Day 264 (19 December 2005), albeit not all variables could be sampled on all sampling days (see Table 1).

The outer rim of each plot ( $0.5 \mathrm{~m}$ wide) was not sampled, to minimise edge effects. The remaining inner area of $9 \mathrm{~m}^{2}$ was divided into 64 subquadrats of $37.5 \times 37.5 \mathrm{~cm}$. On each sampling day, 2 replicate subquadrats, never located next to each other, were randomly chosen beforehand. Depending on the parameter, 1 (macrofauna abundance and biomass, mud content and erosion threshold) or 2 (surface chl $a$, sediment water content and sediment bed level) subquadrats were then sampled in every plot. A portable bridge was used to sample in the centre of the plots so as not to disturb the sediment. All sampling was done from about $2 \mathrm{~h}$ before till $2 \mathrm{~h}$ after low tide. It is highly unlikely that time of sampling within the tidal cycle affected sediment parameters (e.g. water content), since the hydraulic conductivity of this muddy sediment was very low and the sediment remained fully water-saturated during the entire ebb period.
Macrofauna. The benthic macrofauna was sampled to a depth of $40 \mathrm{~cm}$ using a $125 \mathrm{~mm}$ inner diameter stainless steel corer. Samples were fixed with a buffered $8 \%$ formalin solution and taken to the lab in closed containers. The samples were sieved over a $0.5 \mathrm{~mm}$ mesh sieve and preserved using a neutralised $4 \%$ formalin solution with $0.01 \%$ Rose Bengal until they were processed. All macrofauna were sorted, counted and identified to the species level, except for nematodes and tubificid oligochaetes. Macrofaunal biomass was determined according to the methods described in Sistermans et al. (2005). These methods are ISO certified NEN 2000-9001. For further detailed information about the analysis of macrofauna in this experiment see Van Colen et al. (2008, this volume).

We assessed the bioturbatory actions of benthic macrofauna, rather than using a taxonomical classification, to study the effects on sedimentary properties. Gerino et al. (2003) used geochemical criteria for their classification. Here, we categorised the macrobenthos in relation to the erodability of the sediment surface layer, i.e. according to the most direct geomechanical effect for that group sensu Woodin \& Jackson (1979). In this way we assessed the net effect that organisms have on the 'skin' of the sediment. Epi- or endofauna can have a net effect on the sediment surface by (1) diffusing a layer of surface sediment of a given depth, for example Cerastoderma edule (Flach 1996, Gerino et al. 2003), (2) leaving the sediment in a modified form with respect to grain size or critical shear stress after pelletisation of the surface layer, for example Heteromastus filiformis or Hydrobia ulvae, respectively (Cadee 1979, Orvain et al. 2004), (3) disrupting the surface by scraping it due to deposit feeding or grazing by for example Corophium volutator (de Deckere et al. 2001) and (4) modification of the benthic boundary layer and the shear exerted on the surface through tube building by, for example, Pygospio elegans (Bolam \& Fernandes 2003). We, therefore, distinguished between these 4 major sediment surface effects: biodiffusors (BD), pelletisers (PE), surface disruptors (SD) and tube builders (TB). To illustrate the representation of certain geomechanical effects in both the defaunated and control sediment, we used indices of both biomass and abundance of the grouped organisms realising these effects. The index is calculated as follows: $T_{i}=\left(D_{i}-C_{i}\right) /\left(D_{i}+\right.$ $C_{i}$ ), with $T_{i}$ being the treatment index at Day $i$ where $D_{i}$ and $C_{i}$ are the parameter values (abundance or biomass) for an organism group in the defaunated and the control sediment, respectively. When the index is zero, the group is represented in equal densities or biomass in both treatments. When a particular group is overrepresented in the defaunated sediment, the index will approach 1 . Conversely, when a group is overrepresented in the control sediment, the index will tend 
towards -1 . In the control treatment, all groups were always present in substantial abundance and biomass, so that spuriously high values of the ratio statistic due to very low values of the denominator did not occur.

Photopigments, water content and grain size. Sediment material for quantification of photopigments, water content and grain size distribution was extracted from the experimental plots using perspex cores with an inner diameter of $36 \mathrm{~mm}$. To reduce compaction of the sediment during extraction, the plunger of a $100 \mathrm{ml}$ syringe was drawn up the core as it was pushed into the sediment. The cores were placed on dry ice (approx. $-70^{\circ} \mathrm{C}$ ) immediately after extraction to arrest enzymatic reactions and/or reworking by present infauna. Cores intended for photopigment analysis were kept in the dark in a closed PVC sleeve. Upon arrival in the lab, the photopigment cores were kept in the dark and stored at $-80^{\circ} \mathrm{C}$. The cores for sediment analysis were stored at $-20^{\circ} \mathrm{C}$ until processing.

The cores were sliced at depths of 3, 10, 20, 30 and $50 \mathrm{~mm}$. For photopigment analyses, only the top slice of $3 \mathrm{~mm}$ was used, based on the assumption that all living and active MPB is captured within this $3 \mathrm{~mm}$ layer (Kromkamp \& Forster 2003).

Sediment was weighed wet, lyophilised and weighed again dry to yield water mass percentage or absolute water content (Flemming \& Delafontaine 2000) for the 0 to 3,3 to 10 and 10 to $20 \mathrm{~mm}$ depth slices pooled together. Sediment granulometric analysis was carried out on the upper 5 slices. Sediment grain size distribution and especially the percentage of the sediment fraction $<63 \mu \mathrm{m}$ (i.e. mud = silt + clay; Flemming \& Delafontaine 2000, Winterwerp \& van Kesteren 2004) was determined with a Malvern Mastersizer 2000, using laser diffraction.

Sediment for pigment analysis was lyophilised in the dark prior to analysis. Photopigments were extracted from the freeze-dried sediment by adding $10 \mathrm{ml} 90 \%$ acetone, placing it in a ball mill for $20 \mathrm{~s}$ and centrifuging for $5 \mathrm{~min}$ at $1500 \mathrm{rpm}$ (ca. $200 \times \mathrm{g}$ ). The supernatant was analysed by HPLC following Jeffrey et al. (1997).

Bed level and sediment strength. The bed level of the plots was measured relative to fixed and known points in the vicinity, measuring sites of the Dutch National Institute for Coastal and Marine Management (RIKZ). Bed level measurements were performed using a rotating laser mounted on a tripod and a receiving unit on a measuring pole. Bed level values are expressed relative to NAP (Dutch Ordinance Level, similar to Mean Sea Level). Three replicate measurements were haphazardly taken per sampled subquadrat.

The sediment strength, or erosion threshold is taken as a measure of erodability of the sediment under a certain bottom shear, and was measured using a cohesive strength meter (CSM) (Tolhurst et al. 1999, Defew et al. 2002). The CSM uses a jet of water emitted perpendicularly to the sediment surface, disrupting the sediment matrix at the sediment-water interface. A series of tests with increasing pressure of the water jet is performed, according to the 'Mud 6' programme of the CSM Mk III (Sediment Services). The point of incipient erosion was determined as the pressure at which light transmission in the measuring cell decreased below $90 \%$. Care should be taken not to confuse the reported pressure values, expressed in $\mathrm{kPa}$, with bottom shear stress. Tolhurst et al. (1999) provide a conversion equation between eroding pressure measured by the CSM and horizontal shear stress.

Experimental design and statistical procedures. The results were analysed according to a complete randomised (CR) experimental design. The basic statistical design included Time and Treatment as separate categorical and fixed factors, and the Time $\times$ Treatment interaction factor. Due to logistical reasons, we were only able to sample macrofaunal abundance, macrofaunal biomass, percentage mud, absolute water content and surface erosion threshold once per plot. Variables that were sampled in duplicate within plots were surface chl a contents and sediment bed elevation. Depending on the response variable, there were additional levels of variance, namely Plot nested in Treatment and Time $\times$ Plot nested in Treatment (surface chl a) or Subquadrat nested in Plot nested in Treatment and Time $\times$ Subquadrat nested in Plot nested in Treatment (sediment bed elevation) where both Plot and/or Subquadrat were used as random categorical predictors. We were justified in using a classical ANOVA design analysis, even for the factor Time, because errors of individual plots (i.e. deviations of the Treatment-Time mean) were not significantly autocorrelated in time. Moreover, as several of our variables are known to be highly dependent on other factors (e.g. water content depends on mud content), we could introduce these variables as co-factors in the analysis. Using a repeated measurements (RM) design, which would have been the more conservative approach for this analysis, it would have been impossible to include these co-factors. For the sake of consistency, we used CR designs throughout. However, for the analyses where comparison with a RM was possible, we confirmed that there were no differences in model results or interpretation. Normal distribution of the data was ensured by visual inspection of Q-Q plots. Levene's test was used to check for homoscedasticity (homogeneity of variances; Underwood 1997). In cases where the data were heteroscedastic, transformation (either natural logarithm or arcsine square root) was conducted. The data shown in the graphs are untransformed data. Whenever significant effects became apparent, Student-Newman-Keuls (SNK) post hoc test- 
ing (Underwood 1997) was used to investigate how these differences manifested themselves. All univariate analyses were conducted using the STATISTICA data analysis software system, v7.1.

To assess single main effects and interaction effects of the biotic compartments of the system on its erodability, we regressed erosion threshold against chl a concentration, total macrofaunal abundance and total macrofaunal biomass (all variables natural-log transformed). In all cases we departed from a model which contained all explanatory variables and their interactions (i.e. overparameterised) and used a step-wise elimination of parameters, based on Akaike's Information Criterion (AIC; Crawley 2005), to reach a minimal adequate model (MAM). All multiple regressions were conducted in the open-source statistical environment $\mathrm{R}$ (R Development Core Team 2007, R Foundation for Statistical Computing, www.r-project.org).

\section{RESULTS}

\section{Biotic developments}

At the onset of the experiment (removal of the PE sheeting; Day $0=30$ March, 2005) the sediment in the defaunated plots was completely black and anoxic. Replicating Beukema et al. (1999), high numbers of empty shell doublets were observed on the sediment surface.
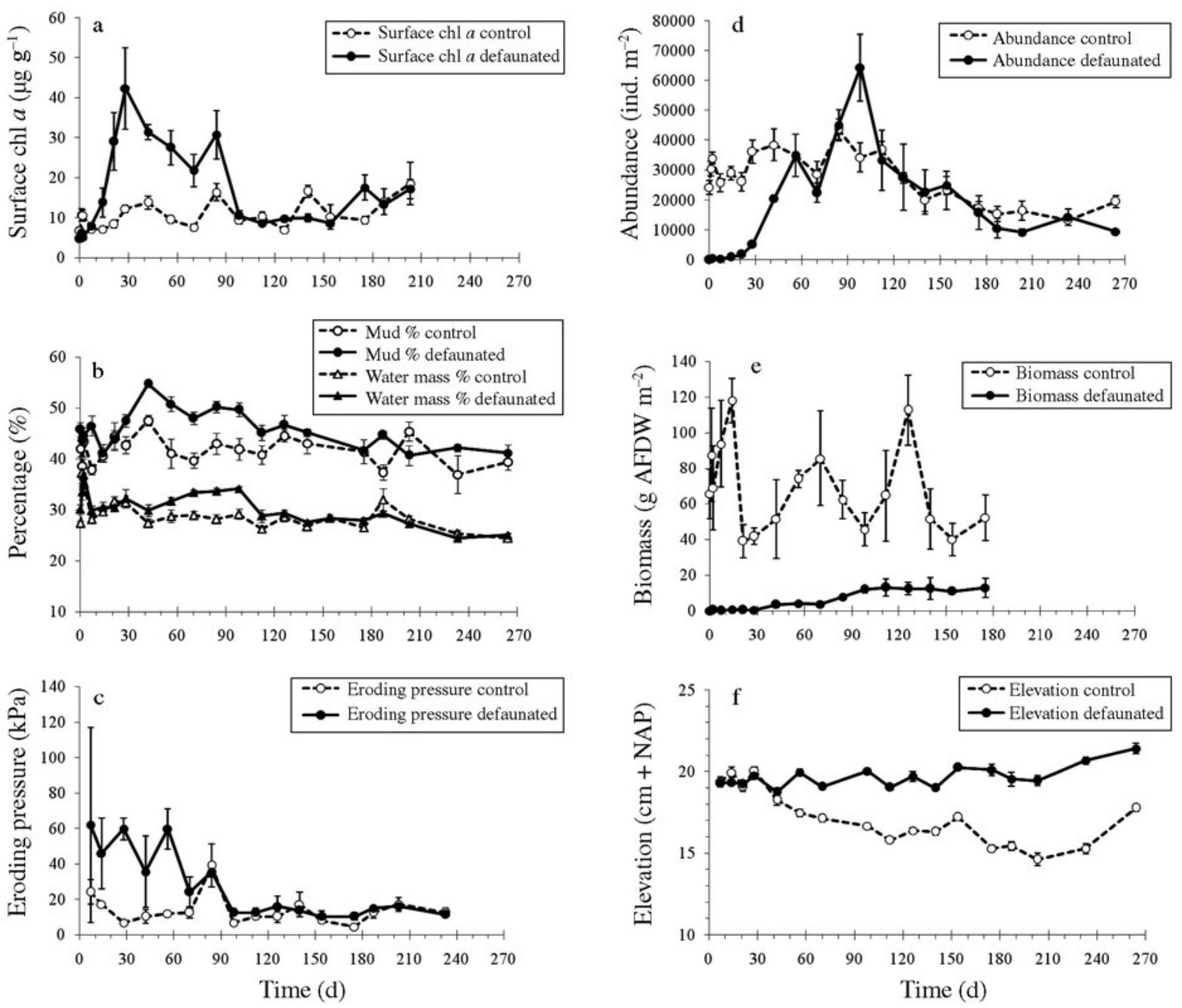

Fig. 2. Mean \pm SEM temporal distribution of biotic and abiotic parameters. (a) Chl a concentration in the top $3 \mathrm{~mm}$ of the sediment, (b) mud percentages (circles) and the water mass percentages (triangles), (c) eroding pressure needed to make the transmission of light in the cohesive strength meter (CSM) sense head drop below $90 \%$, (d) the total abundance (number of ind. per $\mathrm{m}^{2}$ ), (e) the total biomass in grams ash-free dry weight (g AFDW) $\mathrm{m}^{-2}$ and (f) average bed elevation of plots normalised to the Dutch Ordinance Level (Normaal Amsterdams Peil, NAP). Note that in panels (b) and (f) the $y$-axis does not start at 0 
The most conspicuous development within the first month of the experiment was the growth of MPB (Fig. 2a). The control sediment was characterised by fairly constant surface chl a levels, varying between $6.72 \pm 0.89 \mathrm{ug} \mathrm{g}^{-1}$ dry sediment (mean $\pm \mathrm{SEM}$ ) at Day 0 , $10.70 \pm 1.61 \mu \mathrm{g} \mathrm{g}^{-1}$ at Day 1 and $7.05 \pm 0.78 \mu \mathrm{g} \mathrm{g}^{-1}$ at Day 14. The MPB growth pattern in the defaunated sediment was quite different from that in the control sediment. Values started (Day 0) at $4.66 \pm 0.71 \mu \mathrm{g} \mathrm{g}^{-1}$ and increased exponentially to $45.78 \pm 11.04 \mu \mathrm{g} \mathrm{g}^{-1}$ at Day 28. After this initial exponential growth, chl a values decreased, but remained 2 to 3 times higher than control values until Day 84. After ca. 3 mo, at Day 98, $\mathrm{chl} a$ values in the defaunated sediment dropped drastically and then remained constant and low (around $10 \mu \mathrm{g} \mathrm{g}^{-1}$ sediment), similar to the control chl a levels. The factors Time, Treatment and Time $\times$ Treatment interaction had highly significant effects (Table 1).

Table 1. Summary of the ANOVA of the measured environmental (biotic and abiotic) variables. Time: sampling days variables were measured. Variable: the analysed environmental variable with its appropriate transformation in parentheses. Source of variation: the factors taken into the explanatory model for each variable. $\ln =$ natural logarithm transformation; arcsin $=$ arcsine square root transformation. Sign.: significance level ${ }_{i} \sim \mathrm{p} \leq 0.1,{ }^{*}=\mathrm{p} \leq 0.05,{ }^{* *}=\mathrm{p} \leq 0.01,{ }^{* * *}=\mathrm{p} \leq 0.001, !=\mathrm{p} \leq 0.0001$

\begin{tabular}{|c|c|c|c|c|c|c|c|c|}
\hline Time & Variable & Source of variation & SS & df & MS & $F$ & $\mathrm{p}$ & Sign. \\
\hline \multirow[t]{7}{*}{$0-203$} & \multirow{7}{*}{$\begin{array}{l}\text { Surface chl a } \\
\qquad(\ln )\end{array}$} & Intercept & 1296.578 & 1 & 1296.578 & 2853.922 & $<0.0001$ & \\
\hline & & Treatment & 4.679 & 1 & 4.679 & 10.302 & 0.0326 & * \\
\hline & & Plot(Treatment) & 1.816 & 4 & 0.454 & 1.865 & 0.1261 & \\
\hline & & Time & 33.679 & 18 & 1.871 & 7.686 & $<0.0001$ & $!$ \\
\hline & & Time $\times$ Treatment & 18.128 & 18 & 1.007 & 4.137 & $<0.0001$ & $!$ \\
\hline & & Time $\times$ Plot(Treatment) & 17.285 & 71 & 0.243 & 1.404 & 0.0533 & $\sim$ \\
\hline & & Error & 19.591 & 113 & 0.173 & & & \\
\hline \multirow[t]{5}{*}{$0-175$} & \multirow{5}{*}{$\begin{array}{l}\text { Total abundance } \\
\text { macrofauna } \\
(\ln )\end{array}$} & Intercept & 8744.267 & 1 & 8744.267 & 87326.29 & $<0.0001$ & \\
\hline & & Time & 197.799 & 16 & 12.362 & 123.46 & $<0.0001$ & $!$ \\
\hline & & Treatment & 87.829 & 1 & 87.829 & 877.12 & $<0.0001$ & $!$ \\
\hline & & Time $\times$ Treatment & 185.111 & 16 & 11.569 & 115.54 & $<0.0001$ & $!$ \\
\hline & & Error & 6.709 & 67 & 0.100 & & & \\
\hline \multirow[t]{5}{*}{$0-175$} & \multirow{5}{*}{$\begin{array}{l}\text { Total biomass } \\
\text { macrofauna } \\
(\ln )\end{array}$} & Intercept & 601.6332 & 1 & 601.6332 & 1358.26 & $<0.0001$ & \\
\hline & & Time & 57.0282 & 16 & 3.5643 & 8.05 & $<0.0001$ & $!$ \\
\hline & & Treatment & 270.2535 & 1 & 270.2535 & 610.13 & $<0.0001$ & $!$ \\
\hline & & Time $\times$ Treatment & 69.1400 & 16 & 4.3212 & 9.76 & $<0.0001$ & $!$ \\
\hline & & Error & 29.6771 & 67 & 0.4429 & & & \\
\hline \multirow[t]{7}{*}{$0-203$} & \multirow{7}{*}{$\begin{array}{l}\text { Mud }(<63 \mu \mathrm{m}) \\
\quad(\arcsin )\end{array}$} & Intercept & 0.4545 & 1 & 0.4545 & 362.02 & 0 & \\
\hline & & Time & 0.0570 & 17 & 0.0034 & 2.67 & 0.0022 & $* *$ \\
\hline & & Treatment & 0.0054 & 1 & 0.0054 & 4.29 & 0.0420 & * \\
\hline & & Time $\times$ Treatment & 0.0376 & 17 & 0.0022 & 1.76 & 0.0526 & $\sim$ \\
\hline & & $\ln (\mathrm{chl} \mathrm{a})$ & 0.0131 & 1 & 0.0131 & 10.44 & 0.0019 & ** \\
\hline & & Treatment $\times \ln (\mathrm{chl}$ a $)$ & 0.0038 & 1 & 0.0038 & 2.99 & 0.0884 & $\sim$ \\
\hline & & Error & 0.0854 & 68 & 0.0013 & & & \\
\hline \multirow[t]{7}{*}{$0-203$} & \multirow{7}{*}{$\begin{array}{l}\text { Abs. water content } \\
\text { (arcsin) }\end{array}$} & Intercept & 0.0110 & 1 & 0.010958 & 13.99 & 0.0004 & \\
\hline & & Time & 0.0838 & 17 & 0.004931 & 6.30 & $<0.0001$ & $!$ \\
\hline & & Treatment & 0.0005 & 1 & 0.000475 & 0.61 & 0.4389 & \\
\hline & & Time $\times$ Treatment & 0.0071 & 17 & 0.000420 & 0.54 & 0.9248 & \\
\hline & & $\arcsin (\mathrm{mud})$ & 0.0099 & 1 & 0.009871 & 12.60 & 0.0007 & *** \\
\hline & & Treatment $\times \arcsin (\mathrm{mud})$ & 0.0005 & 1 & 0.000517 & 0.66 & 0.4194 & \\
\hline & & Error & 0.0533 & 68 & 0.000783 & & & \\
\hline \multirow[t]{8}{*}{$7-264$} & \multirow{8}{*}{$\begin{array}{l}\text { Elevation } \\
\quad(\ln )\end{array}$} & Intercept & 5083.800 & 1 & 5083.800 & 59324.43 & $<0.0001$ & \\
\hline & & Time & 1.397 & 16 & 0.087 & 13.26 & $<0.0001$ & $!$ \\
\hline & & Treatment & 2.983 & 1 & 2.983 & 34.84 & 0.0041 & $* *$ \\
\hline & & Time $\times$ Treatment & 1.680 & 16 & 0.105 & 15.94 & $<0.0001$ & $!$ \\
\hline & & Plot(Treatment) & 0.342 & 4 & 0.086 & 12.99 & $<0.0001$ & $!$ \\
\hline & & Time $\times$ Plot(Treatment) & 0.415 & 63 & 0.007 & 0.65 & 0.9668 & \\
\hline & & subq $($ Time $\times$ Treatment $\times$ Plot & ot) 1.025 & 101 & 0.010 & 14.92 & $<0.0001$ & $!$ \\
\hline & & Error & 0.273 & 402 & 0.001 & & & \\
\hline \multirow[t]{5}{*}{$7-233$} & \multirow{5}{*}{$\begin{array}{l}\text { Erosion threshold } \\
\qquad(\ln )\end{array}$} & Intercept & 539.9106 & 1 & 539.9106 & 1865.980 & 0 & \\
\hline & & Time & 15.8094 & 15 & 1.0540 & 3.643 & 0.0003 & * \\
\hline & & Treatment & 5.2738 & 1 & 5.2738 & 18.227 & 0.0001 & $!$ \\
\hline & & Time $\times$ Treatment & 6.2272 & 15 & 0.4151 & 1.435 & 0.1682 & \\
\hline & & Error & 14.4672 & 50 & 0.2893 & & & \\
\hline
\end{tabular}




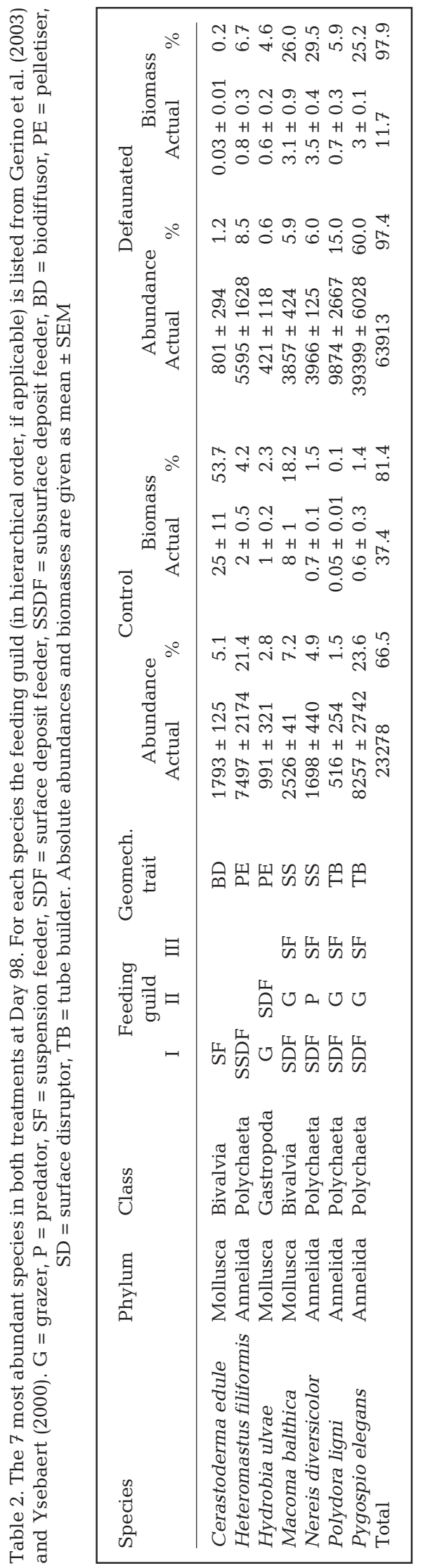

SNK post hoc tests revealed that the significant differences were for the period Day 21 to Day 84. Variances were a power function of the mean in both control and defaunation, and the relation between mean and variance was very similar between the 2 treatments. There was no sign that the defaunated plots were either more similar to each other than the control plots, or that they followed more diverse and independent time courses after the defaunation.

Regression analysis showed that the mean number of macrobenthic species counted in the control sediment was constant over time $\left(p=0.32, r^{2}=0.05\right)$, with an average of $13.5 \pm 0.3$ (SEM) species. The number of species in the defaunated sediment followed a saturation curve (exponential rise to maximum, $\mathrm{p}<0.0001$, $\left.\mathrm{r}^{2}=0.75\right)$ reaching an average of $12.6 \pm 0.6$ after ca. 3 mo.

During the first 1.5 mo of recolonisation (until Day 42) the total macrofaunal abundances (total number of ind. $\mathrm{m}^{-2}$ ) in the 2 treatments were significantly different, where the factors Time, Treatment and Time $\times$ Treatment interaction had highly significant effects (Table 1; Fig. 2d). The total abundance of macrofauna in the defaunated sediment started at zero, increasing to numbers similar to control plots in ca. $8 \mathrm{wk}$. From Day 42 onwards the abundance in the defaunated sediment was still lower, but did not differ significantly from that in the control sediment (SNK, $\mathrm{p}=0.43)$. The abundances of both treatments did not significantly differ until Day 98 when the defaunated sediment reached a total macrofaunal abundance of about twice that of the control (SNK, p = 0.0061). This peak in abundance coincided with the collapse of the MPB concentration.

The conspicuous macrofaunal abundance peak in the defaunated sediment at Day 98 was made up mostly $(60 \%)$ of the tube-dwelling spionid Pygospio elegans (Table 2) (Claparède 1863). Other major constituents of the macrobenthos were the polychaetes Polydora ligni (Webster, 1879), Heteromastus filiformis (Claparède, 1864), Nereis diversicolor (O.F. Müller, 1776) and the tellinid bivalve Macoma balthica (Linnaeus, 1758) (Van Colen et al. 2008). In terms of macrofaunal biomass, $P$. elegans accounted for $25.15 \%$ of the total macrofaunal biomass in the defaunated plots at Day 98. While less abundant in numbers, N. diversicolor contributed $29.45 \%$ and $M$. balthica another $25.97 \%$ to the total biomass. The abundance of cockles (Cerastoderma edule) was about 4 times lower in the defaunated plots, whereas their relative biomass was more than 200 times lower than in the control sediment (Table 2). Apart from Hydrobia ulvae, all species invaded the plots as small juveniles.

Until Day 28, the total biomass (Fig. 2e) in the defaunated plots was 2, and sometimes even 3 (Day 14) 

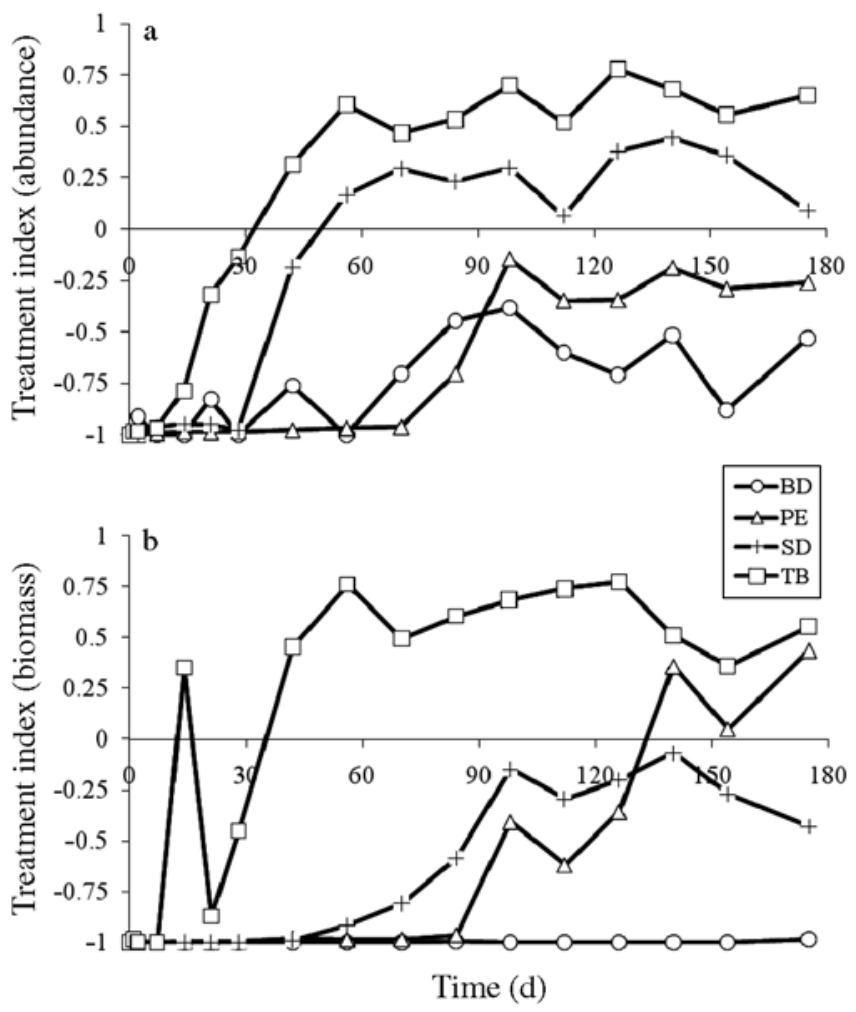

Fig. 3. Treatment index for the parameters (a) abundance and (b) biomass of the 4 geomechanical groups, where $0=$ equal representation in both treatments, $-1=$ highly overrepresented in the control sediment and $1=$ highly overrepresented in the defaunated sediment. $\mathrm{BD}=$ biodiffusor,

$\mathrm{PE}=$ pelletiser, $\mathrm{SD}=$ surface disruptor, $\mathrm{TB}=$ tube builder

orders of magnitude lower than in the control plots. Between Day 28 and Day 42 the total biomass in the defaunated plots increased with an order of magnitude, from 0.36 to $3.48 \mathrm{~g} \mathrm{AFDW} \mathrm{m}^{-2}$, and remained stable for until Day 70. The total biomass then increased to $7.77 \mathrm{~g} \mathrm{AFDW} \mathrm{m}^{-2}$ at Day 84 and $12.03 \mathrm{~g}$ AFDW $\mathrm{m}^{-2}$ at Day 98, after which it remained stable.

Using our geomechanical classification of the abundant macrobenthic species, we calculated a treatment index $\left(T_{i}\right)$ of the representation of the defined geomechanical traits in both treatments (Fig. 3), in terms of abundance and biomass. After 1.5 mo (Day 42), TB became more numerous in the defaunated sediment coinciding with stable, non-eroding sediment, while SD followed 2 wk later (Fig. 3a). The geomechanical traits biodiffusion and pelletisation were more numerous in the control sediment during the entire course of the experiment, although PE were closer to zero (i.e. equal representation over treatments) than BD. In terms of biomass, only TB occurred in higher numbers in the defaunated sediment (Fig. 3b). Only in a later stage did PE become somewhat over-represented in the defaunated sediment. The BD biomass attained a $T_{i}$ of ca. -1 throughout the entire experiment, which states its continuous high under-representation in the defaunated sediment. The surface disruptors tend more towards zero but remain over-represented in the control sediment.

\section{Abiotic developments}

After about 1.5 mo (Day 56) the defaunated plots were visibly more elevated than the surrounding sediment and remained this way throughout the course of the experiment (Table 1, Figs. 2f \& 4). Also, the surface ripples normally seen on the control and on the surrounding ambient sediment were absent in the defaunated plots. This difference was not only caused by accretion of suspended sediment on the treated plots (F. Montserrat et al. unpubl. data), but mainly by erosion of the surrounding ambient sediment. Later in the experimental period (Day 203) there was overall deposition as the bed level increased in both treatments, but the defaunated plots remained significantly higher relative to NAP than the control plots.

The sedimentology of the top $2 \mathrm{~cm}$ was also found to differ between the treatments (Fig. 2b). In the defaunated sediment, the percentage of mud was higher relative to the control sediment with significant effects for the factors Time and Treatment, but not for the Time $x$

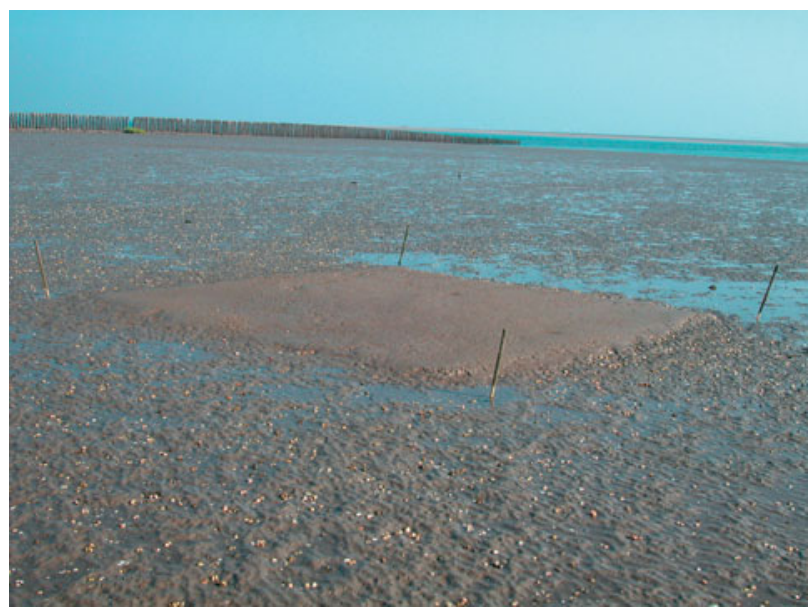

Fig. 4. A defaunated plot, which was not sampled, ca. 2 mo after removal of the polyethylene cover. The sides of the square plot (corners designated with bamboo sticks) were $4 \mathrm{~m}$ in length. Note the different appearance of the plot compared to the surrounding ambient sediment. The sediment surface within the plot is very flat and devoid of faunal surface activity, unlike the surrounding sediment, which also displays sand ripples as a result of wave action 
a

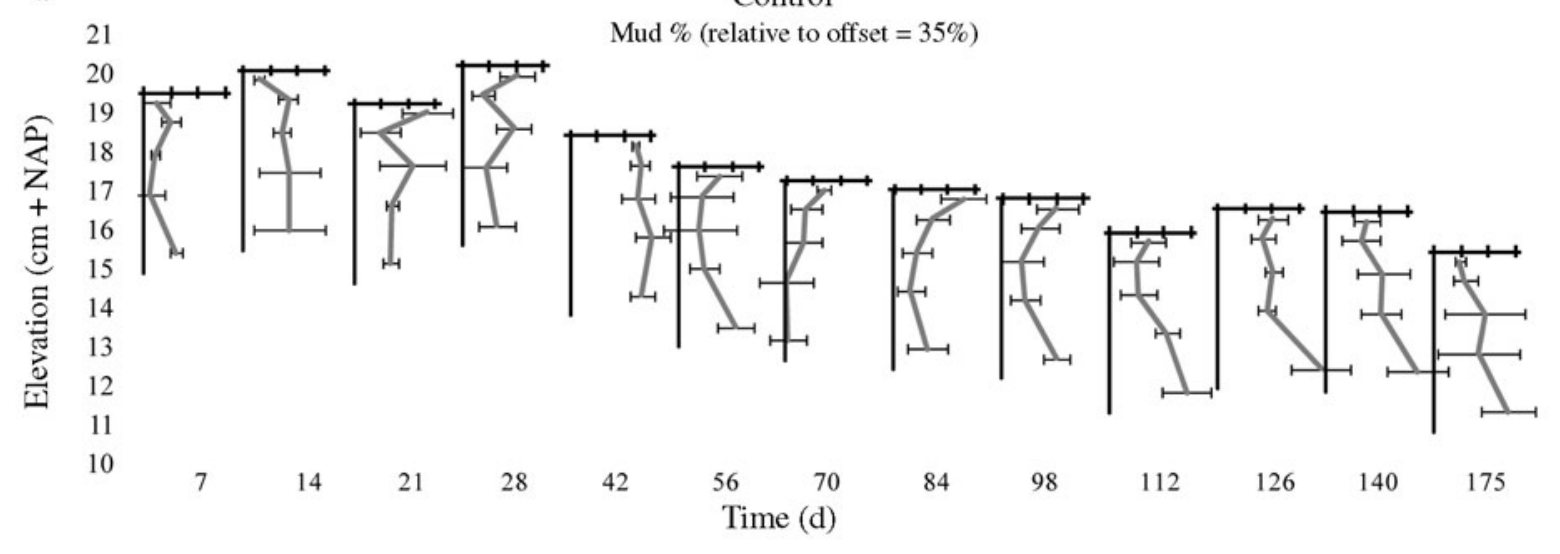

b

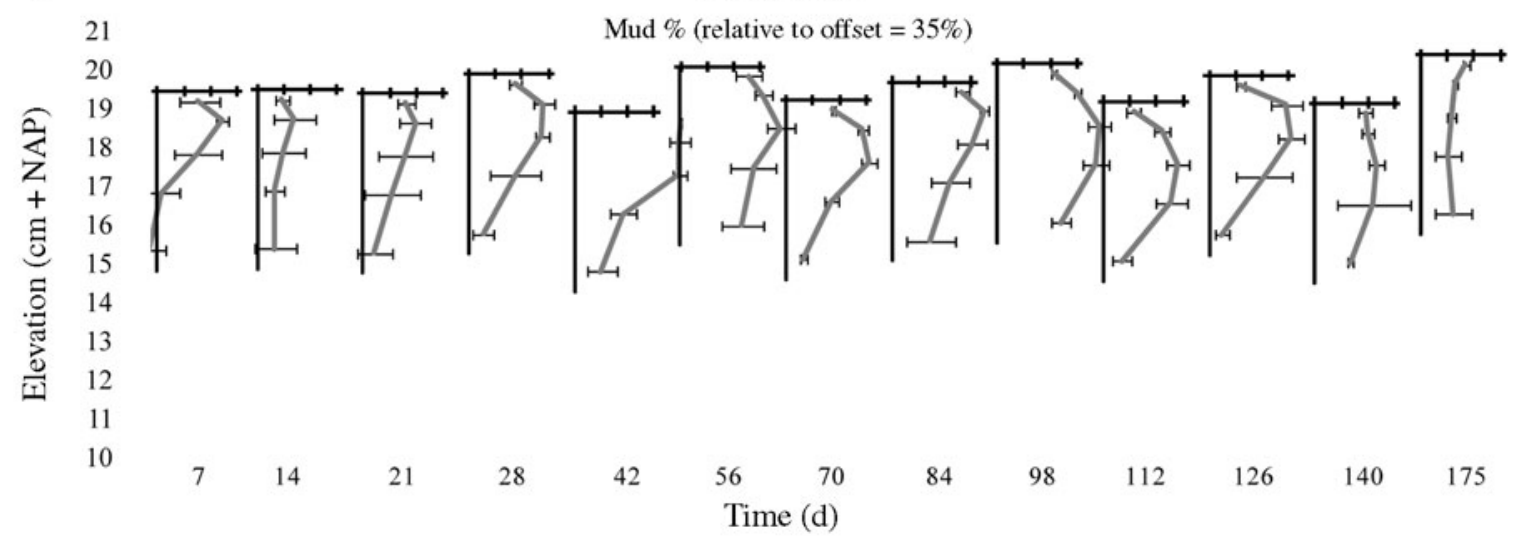

Fig. 5. The development of average mud percentage $(\%<63 \mu \mathrm{m})$ over time for the sediment layers $0-3,3-10,10-20,20-30$ and 30-50 $\mathrm{mm}$ in (a) control sediment and (b) defaunated sediment. The small sub-diagrams depict average percentage mud \pm SEM, relative to an offset (base value) of $35 \%$, for a given time in days after the start of the experiment and are positioned according to the sediment bed level in $\mathrm{cm}$ above NAP (Dutch Ordinance Level), which corresponds to the overall $y$-axis. The unit on the $x$-axes of each of the sub-diagrams is $5 \%$

Treatment interaction factor (Table 1). During the initial weeks of the experimental period (Day 21 to Day 42) mud percentage in the control sediment also increased somewhat but remained lower than in the defaunated sediment. Depth distribution of mud in the top layers showed interesting patterns (Fig. 5). The top layer of the control sediment accumulated mud from Day 21 to Day 40, after which it decreased again slightly (Fig. 5a). As the surface eroded away and given the same coring depth, deeper layers containing more mud were reached. Thus, the mud profile obtained was a slightly concave one. The defaunated sediment, however, seemed to accumulate mud rather quickly in the first $6 \mathrm{wk}$, although the top layer always contained less mud than underlying layers (Fig. 5b). The exception was Day 40 where the depth-averaged mud percentage over the top $2 \mathrm{~cm}$ was around $55 \%$ against ca. $47 \%$ for the control sediment. As the bed level remained rather constant, so did the mud percentage of the deepest layers, yielding a convex mud profile. Around Day 120, when faunal abundance, and in particular abundance of deeper-burrowing species was restored (Van Colen et al. 2008), the pattern of mud depth-distribution returned to that of the controls.

The depth-averaged absolute water content $\left(\mathrm{W}_{\mathrm{a} i}\right.$ arcsine transformed) in the top $2 \mathrm{~cm}$ of sediment showed a significant effect of Time (Table 1, Fig. 2b), but without a significant effect for either Treatment or the Time $\times$ Treatment interaction terms. Instead, the factor mud content (arcsine transformed) did have a significant effect on the difference in $\mathrm{W}_{\mathrm{a}}$. Water content appeared to follow mud content closely, with some seasonal influence on the relationship.

One week after the removal of the plastic sheeting (Day 7) the defaunated sediment showed a high variability in erosion threshold. After 2 wk (Day 14), the 
Table 3. Parameters estimates and their respective SE for the multiple regression of erosion against total macrofaunal abundance, total macrofaunal biomass and [chl a]

\begin{tabular}{|lrrrc|}
\hline & Estimate & SE & \multicolumn{1}{c}{$t$} & $\mathrm{p}$ \\
\hline Intercept & 3.00 & 0.90 & 3.34 & 0.0015 \\
$\ln ($ abundance) & -0.23 & 0.11 & -2.07 & 0.0429 \\
$\ln ($ biomass $)$ & -1.36 & 0.54 & -2.53 & 0.0142 \\
$\ln ([$ chl a]) & 0.79 & 0.18 & 4.35 & $5.38 \times 10^{-5}$ \\
$\ln ($ abundance) $\times$ & 0.13 & 0.05 & 2.40 & 0.0197 \\
$\ln$ (biomass) & & & & \\
\hline
\end{tabular}

defaunated sediment was characterised by a higher erosion threshold than the control sediments, and this lasted throughout the first 2 mo. The largest difference between the treatments coincided with the highest surface chl a values (MPB biomass) at Day 28. At Day 70 the threshold converged to the control sediment level. Both treatments experienced a last increase at Day 84, decreased again and remained at similar levels until the end of the experiment (Fig. 2c). There was a significant effect for both the factors Time and Treatment, but not for the Time $\times$ Treatment interaction factor with $\mathrm{p}=0.1682$ (Table 1 )

We regressed erosion threshold against total macrofaunal abundance, total macrofaunal biomass and chl a (all variables natural log-transformed) for both treatments separately and for both treatments combined. In the cases of both the control plots and defaunated plots separately, no minimal adequate model (MAM) was reached; i.e. no significant effects could be found for any of the variables or their interactions, either 2- or 3way. However, when both treatments were combined, a MAM could be established, containing the parameters abundance, biomass, chl $a$ and the interaction between abundance and biomass (Table 3). Consecutive simple regressions (both treatments combined) of erosion against abundance, biomass and chl a showed that these variables separately could account for $13 \%$ $(\mathrm{p}=0.0033), 30 \%(\mathrm{p}<<0.0001)$ and $32 \%(\mathrm{p}<<0.0001)$ of the variance, respectively (Fig. 6). The fitted multiple regression model, containing the abovementioned 4 parameters (see also Table 3 ) had an overall significance level of $\mathrm{p}<<0.0001$ with multiple $\mathrm{r}^{2}=0.4833$.

\section{DISCUSSION}

\section{Microphytobenthos regulation}

Whereas the MPB reacted quickly and strongly and recolonised the defaunated plots in a matter of days, the macrofaunal abundance took several weeks to reach control levels. In the absence of grazing macrofauna, MPB experienced a period of exponential growth, whereas in the control sediment MPB was more constant as it was simultaneously being consumed, disturbed or buried by the intact macrofaunal community. Fig. 6a shows that, due to the presence of grazing or sediment-disturbing macrofauna, there is a narrower range of MPB abundance in the control plots than in the defaunated plots. The importance of macro-
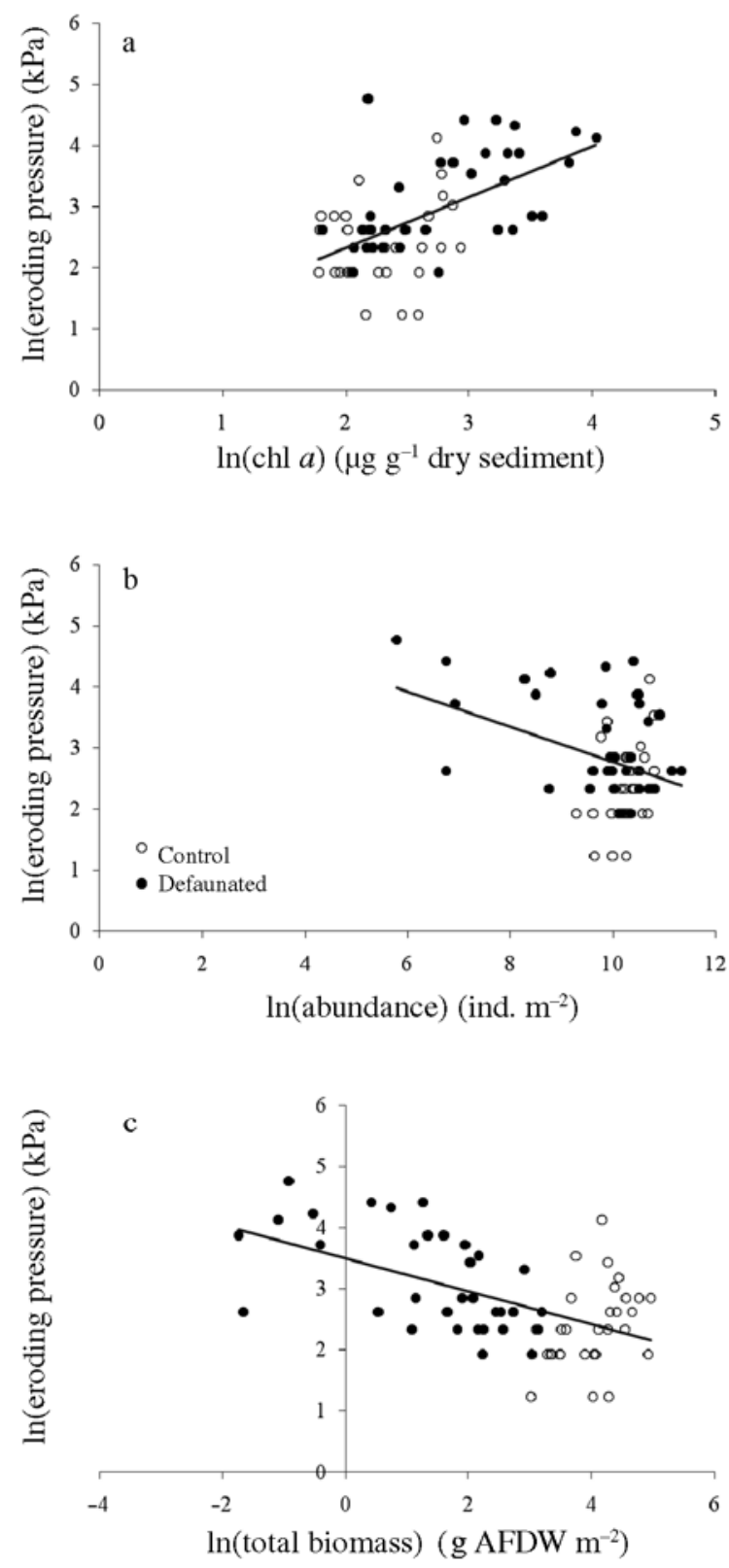

Fig. 6. Simple regression graphs of erosion threshold against (a) chl $a_{\text {, }}$ (b) total macrofaunal abundance, and (c) total macrofaunal biomass; $\mathrm{O}=$ control, $\bullet=$ defaunated. Grey solid lines: trendlines for both treatments combined. All variables are natural-log transformed 
faunal checks on MPB has been reported in a number of studies (Blanchard et al. 2000, de Deckere et al. 2001).

The increased sediment strength during Day 14 to Day 56 of the experiment can be attributed to the increased abundance of benthic diatoms, which form a very strong, yet flexible layer on the sediment surface. This armouring acts as a first-order binding mechanism of the cohesive sediment (Holland et al. 1974, de Boer 1981, Paterson 1989, de Brouwer et al. 2003b) and causes the erosion threshold to be significantly higher than in the control plots. Mud content of the defaunated sediment also increased during the initial period of the experiment. However, this increase only started after some time, which was probably needed to develop a sufficiently large diatom mat capable of entraining mud from the water column. Water content of the sediment was not lower (on the contrary, even slightly higher) in the defaunated than in the control sediment, ruling out the possibility that increased sediment stability was caused by compaction only during the defaunation treatment.

Very recently, Larson \& Sundbäck (2008) demonstrated the key role of diatoms in the recovery of ecosystem functions in shallow marine systems. In their experiments, diatoms appeared to possess an enormous resilience against hypoxic events and were able to re-oxygenate the top layer of experimentally defaunated sediment in less than a week. MPB survival of low-oxygen conditions ensures that recolonisation by higher trophic levels is not limited by lack of primary production.

By providing ample food supply and by stabilising the sediment surface, MPB thus prepared favourable conditions for pioneer species. After recruitment and recolonisation started in the defaunated plots, the community developed towards a rather different composition from that in the control plots (Van Colen et al. 2008). Similar species were present in both treatments but when considering the geomechanical traits of those species their representation differed greatly. More specifically, TB attained both positive abundance (Fig. 3a) and biomass (Fig. 3b) indices from around 1 mo after the start of the experiment. The opportunist spionid and major constituent of the tube-building pioneers, Pygospio elegans, is a natural surface deposit feeder, which changes diet during its ontogeny (Hentschel 1998). While adults derive their nutrition from both MPB and phytodetritus, settled larvae and small juveniles forage mainly on benthic microalgae. The settled spionids foraged on the thick MPB layer, grew at a high rate and reached high densities (Van Colen et al. 2008) within the same period as the MPB was blooming on the defaunated plots.

\section{Sediment characteristics}

Although the sediment variables showed a clear relation with MPB in the first phase, we observed a decrease in the difference in erosion threshold and mud content approximately 1 mo before the MPB biomass collapsed. The decrease of the erosion threshold and the start of net loss of mud in the defaunated sediment coincided in time, suggesting that this was a consistent change in the sediment behaviour. To add to this consistency, the mud content showed the same pattern in both treatments. The much lower abundance and biomass of macrofauna combined with a well-developed diatom mat in the defaunated sediment caused the mud content to increase before it started to converge to constant control levels after Day 42. It appears that this moment of convergence coincides with the moment where macrofaunal abundance first reaches control levels (i.e. is not significantly different from that of the controls). The pioneer community then started to inhibit the armouring effect of the MPB by grazing and disturbance of the sediment surface.

When the macrofauna abundance experienced an overshoot (around Day 98), mud was lost faster in the defaunated than in the control plots (Figs. 2b \& 5b). This is backed up well with the surface disrupting macrobenthos (SD) abundance attaining a positive $T_{i}$ at that time. The over-representation of this group in the defaunated plots (Fig. 3a) induced a decrease in erosion threshold (Fig. 2c) and a faster loss of mud. Thus, macrofaunal influence seems to have overtaken the stabilising influence of MPB after about 2.5 mo.

Instead of being eroded after the disappearance of the protective effect of the diatom mat, the defaunated sediment remained more elevated than both the surrounding ambient sediment and the control plots. In fact, the sediment in the control plots was found to erode while the defaunated sediment remained at more or less the same level. Mud percentages did increase significantly in the defaunation treatment, but the increase was not extremely high and did not last for months. However, Mitchener \& Torfs (1996) reported significant increases of the $\tau_{\text {crit }}$ (departing from a pure sand bed) at mud contents between 30 and $50 \%$. Visual inspection of the sediment, as well as photographic documentation (Fig. 4) suggested that the increase measured in this experiment was sufficient to change the sediment behaviour from a slightly noncohesive, ripple-forming state in the controls, to a more cohesive, smooth surface in the defaunated treatment (Winterwerp \& van Kesteren 2004). Independent measurements taken by RIKZ ca. $1 \mathrm{~km}$ east of our experimental plots in the same intertidal area show erosion in the order of 2 to $3 \mathrm{~cm}$ between May and November 
2005 (G. Liek, RIKZ, pers. comm.). These bed elevation measurements are consistent with our own findings in the present study.

The subsurface lining of plastic sheeting hardly, if at all, affected the ripple migration within the defaunated plots. Not only does ripple migration occur mainly by sediment transport at the surface (van Rijn 1993), but also the period of the ripples in the ambient sediment was of a spatial scale (cm; Fig. 4) 2 orders of magnitude smaller than the spatial scale of the defaunated plots (m). If the subsurface lining had prevented ripple migration, this would have been observed primarily at the edges of the plots, and ripple formation would have been possible and visible in the middle part of the plots. This was not the case in our experiment.

\section{Macrofaunal effects}

The dependence of recolonisation on larval recruitment makes the succession dependent on the timing of opening the plots, because larvae of many species are only available during short periods. We timed our experiment to allow for recruitment of all important species (Ysebaert 2000). Some auxiliary plots were opened later in the year for other measurements (not discussed here) and faunal data of these plots showed that community species composition was very time-dependent (i.e. differed with availability of larval recruits). However, the sequence of faunal group composition was very similar, as was the sequence of sediment characteristics. Thus, we feel that our results are robust against these changes, provided that at least a minimum number of species is available for recruitment.

Tube building macrobenthos (TB) attained a positive $T_{i}$ for both abundance and biomass after only 1 mo. Their very high numbers (>20000 ind. $\mathrm{m}^{-2}$ at Day 42 to ca. 40000 ind. $\mathrm{m}^{-2}$ at Day 98; Van Colen et al. 2008) coincided with the more elevated position of the defaunated plots as compared to the control plots and surrounding ambient sediment as described above in 'Abiotic developments'. In high densities this group effectively decreases erosion (Woodin \& Jackson 1979, Jumars \& Nowell 1984a,b, Murray et al. 2002). By creating milder hydrodynamics locally, they induced an increase in retention of mud at the sediment surface. Widdows et al. (2000) observed similar high densities of Pygospio elegans tubes protecting the sediment from erosion by increasing the height of the benthic boundary layer or even by replacing it to a higher position in the water column. Friedrichs et al. (2000) used the parameter roughness density (RD) to study flow attenuation in idealised tube 'meadows'. Assuming a tube diameter of $1 \mathrm{~mm}$, the RD in the defaunated plots in our study would be around 0.03 at the time of the
P. elegans abundance peak (Day 98). This RD value corresponds to RD values at and above which flow attenuation and net deposition of sediment took place in the work of Friedrichs et al. (2000). Bolam \& Fernandes (2003) also found that in P. elegans patches in the Firth of Forth (SE Scotland) both silt/clay content and organic matter content were significantly higher. Both of these variables are known to contribute to a higher cohesiveness of the sediment (Winterwerp \& van Kesteren 2004). Also, these tube meadows can better trap finer sediment fractions from the overlying water column. Rabaut et al. (2007) describe a similar phenomenon in aggregations of the tubeworm Lanice conchilega on the Belgian continental margin. Besides being associated with higher local species diversity, these Lanice 'reefs' alter hydrodynamics, retain sediment locally, and appear elevated above the surrounding sediment. In light of these very consistent findings, we postulate that the tubes formed by P. elegans in such high densities 'root down' the sediment, entrain mud particles and prevent it from eroding away.

The stabilising effect of the tube meadows was not directly reflected in the erosion threshold measurements. This can be partly attributed to the way the CSM applies water pressure to the sediment surface. The CSM uses a water jet acting perpendicularly on the sediment. A diatom mat is a more or less uniform layer on and integrated with the surface sediment, able to withstand (up to a certain point) the water pressure exerted by a CSM water jet. The spionid tubes can be seen to act as miniature vegetation sensu Scoffin (1970) and Woodin \& Jackson (1979), where the meadow of tubes reduces the incident fluid momentum on the bed and retains (i.e. prevents resuspension of) the sediment but cannot counteract the perpendicular CSM water jet. Many other authors have used the CSM in different field and in lab experiments, all yielding consistent results. In our experiment there was not only a clear difference in erosion threshold between the treatments in the first $2 \mathrm{mo}$, but also little variability around the mean erosion threshold values in the control sediment, indicating that the resulting values do give a consistent measure of sediment surface strength. Even if the CSM does not give a strict quantitative measure of undrained shear strength of different sediments, it most certainly yields a qualitative difference regarding the erosion threshold of the 2 treatments. Widdows et al. (2007) demonstrated that the CSM is best in detecting the stabilising effect of MPB aggregates and suggest a field annular flume for measuring macrobenthic effects on erosion threshold and rate in situ. We could not deploy such a flume due to obvious experimental and logistical constraints. Sediment bed level did remain higher for several months after the erosion threshold, indicating the stabilising effect of the highdensity tubeworm population. 


\section{Intricate interactions}

Simple regression analysis of CSM eroding pressure results against the 3 biotic variables 'total macrofaunal abundance', 'total macrofaunal biomass' and 'sediment surface chl a content' all showed significant relations, but the relations were not particularly strong, not particularly useful for extrapolation and not particularly new for benthos-sediment interactions related research. Multiple regression analysis for both treatments separated did not yield very interpretable results, either. The range of values for both treatments separately was relatively small, and especially so for the control plots. When both treatments were combined, the range of values was larger and highly significant effects became apparent (Fig. 6). This is shown best in Fig. 6c, where the range of biomass values of the defaunated plots (black circles; starting at very low values) are in line with that of the control plots (white circles). The MAM, which could be established, contained all 3 variables (abundance, biomass and chl a as well as the interaction between abundance and biomass), and was able to explain slightly less than half of the variance (multiple $\mathrm{r}^{2}=0.4833$ ).

It is possible that factors we did not measure in this experiment would have correlated better with the CSM measurements. In particular, direct measurements of EPS could have been more meaningful than chl a measurements, which are only a proxy of MPB biomass (Underwood \& Paterson 1993) and not of MPB activity. However, total EPS measurement also neglects important chemical differentiation between different EPS classes, and is therefore not guaranteed to better reflect sediment strength than MPB biomass measures (de Brouwer et al. 2002, Wolfstein et al. 2002).

In light of the macrobenthic recolonisation recorded in our experiment (see also Van Colen et al. 2008), we attribute the interaction term Abundance $\times$ Biomass to a situation in which high densities of juvenile macrofauna (high density, low biomass) caused less erosion than a population of the same density which consists of adult individuals (high density, high biomass). The former would be the case in the defaunated plots after ca. 3 mo where high numbers of recruits had settled, the latter in the case of a natural situation.

Daborn et al. (1993), in their multidisciplinary field study in the Bay of Fundy, showed how seasonally regulated trophic cascades can lead to changing patterns in sediment dynamics. Here, we would like to add the feedback of the macrobenthos to the sediment.

An important pattern in the development of the macrofaunal community in the defaunated sediment was the highly negative treatment index $\left(T_{i}\right)$ of biodiffusing (BD) macrobenthos. Biodiffusion (Gerino et al.
2003) is one of the processes which keeps the sediment surface loose and increases bottom roughness, rendering it more susceptible to erosion (Woodin \& Jackson 1979). The BD group was made up of $>90 \%$ of the common cockle Cerastoderma edule. The highly negative $T_{i}$ could be attributed to the absence of large, adult $C$. edule in the defaunated sediments. C. edule is a mobile, suspension feeding bivalve (Kamermans et al. 1992) which lives in the top 2 to $5 \mathrm{~cm}$ of the sediment. Ciutat et al. (2007) conducted a flume study in which suspended sediment concentrations $\left(\mathrm{mg} \mathrm{l}^{-1}\right)$ and erosion rate $\left(\mathrm{g} \mathrm{m}^{-2} \mathrm{~s}^{-1}\right)$ increased significantly as a function of increasing current speed and increasing cockle density. In addition, increased cockle density caused the critical erosion velocity ( $U_{\text {crit, }}$ the current velocity needed to erode $1 \mathrm{~g} \mathrm{~m}^{-2}$ of sediment) to decrease significantly. With geomechanical effects being highly density-dependent (Woodin \& Jackson 1979), it should be noted that the maximum average cockle density recorded in the control plots of our study exceeded the maximum density used by Ciutat et al. (2007) by a factor of 10. By continuously mixing and disturbing the sediment, adult cockles can also cause a reduction of the presence of other pioneer species among which is Pygospio elegans (Woodin \& Jackson 1979, Flach 1996). Bolam \& Fernandes (2003) observed temporal mutual exclusion of $P$. elegans and $C$. edule in a Scottish intertidal area. Rhoads \& Young (1970) identified this as 'trophic amensalism', with the cockles being the inhibitory group and the spionids the amensals. However, Snelgrove \& Butman (1994) falsified most claims of the theory of trophic amensalism, mainly on the ground that, through modifications applied in several examples, it lacks generality. In terrestrial ecology, the term 'competitive displacement' is used to describe this type of organism-environment-organism interaction (Osakabe et al. 2006). Although not addressed in this study, the exceptionally high abundances of $P$. elegans also might have had an adverse effect on the larval settlement of other species, either directly through predation or indirectly (Cummings et al. 1996).

The drastic over-representation of tube building (TB) species in the defaunated plots caused a reduction in surface erosion and sediment resuspension. Furthermore, because of the severe under-representation of biodiffusing (BD) cockles, and the high absolute and relative biomass they represent in the control plots, the defaunated plots did not undergo the continuous sediment reworking, erosion and consequent decrease in sediment bed level as was the case in the control plots. We postulate that, preceded by the initially undisturbed and sediment-stabilising diatom mats, these factors combined (high TB density, low BD density and biomass) accounted for the largest part of the differences in sediment behaviour. 


\section{Biogeomorphological modelling}

Paarlberg et al. (2005) modelled the effects of biological activity on a salt marsh-mudflat complex in the Paulinapolder intertidal area where our study was conducted. They modelled a situation devoid of biological activity (i.e. no macrobenthos), a situation where there is maximum stabilisation by microphytobenthos, and a situation where there is maximum destabilisation by macrobenthos. In the latter situation their model showed that the sediment was eroded. The model outcomes showed an increase in depth-averaged mud content in both the azoic and maximum stabilisation situations. Also, a bed level of about $10 \mathrm{~cm}$ lower than the azoic and maximum stabilisation scenarios was attained in the maximum destabilisation situation. A further situation was introduced where biological activity varied spatially in a $60 \times 60 \mathrm{~m}$ chessboard pattern. In this situation the bed level showed the same difference of about $10 \mathrm{~cm}$. Although the spatial scale in this model study differs somewhat from the present experiment, the model outcomes, with strong macrobenthos-sediment controls, are in the right order of magnitude, and qualitatively in accordance with our observations (Fig. 2). A logical next step in modelling is to add the dynamics of organism-sediment interactions, in such a way that the coupled physical-biological system can be used to explore time dynamics of the system. Such an approach has been useful in explaining salt marsh development (Temmerman et al. 2007). Studies by Le Hir et al. (2007) and by Wood \& Widdows (2002) have included the temporal and seasonal dynamics of both MPB and macrofauna effects and arrive at similar qualitative and quantitative conclusions. Both studies conclude that MPB effects are fairly well understood, relatively easy to model and overall stabilising. In both studies macrofauna effects are considered to be highly variable and difficult to unravel. Using the natural succession of benthic macrofaunal species our study has revealed separate effects of geomechanically functional groups in the field.

\section{CONCLUSION}

After an intense anthropogenic disturbance event, recolonisation of the site by the various functional groups of an intertidal community followed different dynamics. The groups of organisms affected each other through their influence exerted on the immediate environment. The time taken for the abiotic compartments to revert to what we perceive as a normal state is set by the speed of succession of the macrobenthic community as a whole. During a lag phase with low macrobenthic abundance, exponential growth of microphytobenthos and concomitant geomechanical changes in the sediment dominate the developments. This may facilitate recruitment of the macrobenthos, which, once sufficiently abundant, interacts intensely but in a complex way with microphytobenthos, sediment mud content (sediment cohesiveness) and sediment strength. The net effect of these interactions is slightly erosive, compared to a defaunated state. As demonstrated by this study, the dominant benthic macrofauna largely determines sediment behaviour.

Acknowledgements. We offer gracious thanks to J. van Soelen, B. Koutstaal, D. Peelaers and B. Beuselinck as well as the Masters students for their enormous efforts during the field work. K. van den Meersche and F. Rossi are both kindly thanked for their patient advice on statistics. C. Kleppe, J. Sinke, Y. van der Maas, M. Houtekamer, H. Francke, D. van Gansbeke and D. Schram are thanked for their help in processing the sediment for pigment, granulometric and nutrient analyses. C. Woulds, J. Middelburg, H. Winterwerp and M. Vos proofread the manuscript in an earlier or later stage and provided valuable advice and comments. This research was supported by the Dutch Technology Foundation STW, applied sciences division of NWO and the Technology Program of the Ministry of Economic Affairs and the Institute for the Promotion of Innovation through Science and Technology in Flanders, Belgium (IWT Vlaanderen). This is NIOO-KNAW publication no. 4452 .

\section{LITERATURE CITED}

Andersen TJ, Jensen KT, Lund-Hansen L, Mouritsen KN, Pejrup M (2002) Enhanced erodibility of fine-grained marine sediments by Hydrobia ulvae. J Sea Res 48:51-58

- Banta GT, Holmer M, Jensen MH, Kristensen E (1999) Effects of two polychaete worms, Nereis diversicolor and Arenicola marina, on aerobic and anaerobic decomposition in a sandy marine sediment. Aquat Microb Ecol 19:189-204

Barille L, Cognie B (2000) Revival capacity of diatoms in bivalve pseudofaeces and faeces. Diatom Res 15:11-17

Beukema JJ, Flach EC, Dekker R, Starink M (1999) a longterm study of the recovery of the macrozoobenthos on large defaunated plots on a tidal flat in the Wadden Sea. J Sea Res 42:235-254

Blanchard GF, Guarini JM, Provot L, Richard P, Sauriau PG (2000) Measurement of ingestion rate of Hydrobia ulvae (Pennant) on intertidal epipelic microalgae: the effect of mud snail density. J Exp Mar Biol Ecol 255:247-260

Bolam SG, Fernandes TF (2002) Dense aggregations of tubebuilding polychaetes: response to small-scale disturbances. J Exp Mar Biol Ecol 269:197-222

Bolam SG, Fernandes TF (2003) Dense aggregations of Pygospio elegans (Claparede) effect on macrofaunal community structure and sediments. J Sea Res 49:171-185

$>$ Bouma TJ, De Vries MB, Low E, Peralta G, Tanczos IC, Van de Koppel J, Herman PMJ (2005) Trade-offs related to ecosystem engineering: a case study on stiffness of emerging macrophytes. Ecology 86:2187-2199

Cadee GC (1979) Sediment reworking by the polychaete Heteromastus filiformis on a tidal flat in the Dutch Wadden Sea. Neth J Sea Res 13:441-456

Ciutat A, Widdows J, Pope ND (2007) Effect of Cerastoderma edule density on near-bed hydrodynamics and stability of 
cohesive muddy sediments. J Exp Mar Biol Ecol 346: $114-126$

Crawley MJ (2005) Statistics: an introduction using R. John Wiley \& Sons, Chichester

> Cummings VJ, Pridmore RD, Thrush SF, Hewitt HE (1996) Effect of the spionid polychaete Boccardia syrtis on the distribution and survival of juvenile Macomona liliana (Bivalvia: Tellinacea). Mar Biol 126:91-98

Daborn GR, Amos CL, Brylinsky M, Christian H and others (1993) An ecological cascade effect: migratory birds affect stability of intertidal sediments. Limnol Oceanogr 38: 225-231

de Boer PL (1981) Mechanical effect of micro-organisms on intertidal bedform migration. Sedimentology 28:129-132

de Brouwer JFC, Bjelic S, de Deckere EMGT, Stal LJ (2000) Interplay between biology and sedimentology in a mudflat (Biezelingse Ham, Westerschelde, The Netherlands). Cont Shelf Res 20:1159-1177

de Brouwer JFC, Ruddy GK, Jones TER, Stal LJ (2002) Sorption of EPS to sediment particles and the effect on the rheology of sediment slurries. Biogeochemistry 61:57-71

de Brouwer JFC, de Deckere EMGT, Stal LJ (2003a) Distribution of extracellular carbohydrates in three intertidal mudflats in Western Europe. Estuar Coast Shelf Sci 56:313-324

de Brouwer JFC, Neu TR, Stal LJ (2003b) On the function of secretion of extracellular polymeric substances by benthic diatoms and their role in intertidal mudflats: a review of recent insights and views. In: Kromkamp JC, De Brouwer JFC, Blanchard GF, Forster RM, Creach V (eds) Microphytobenthos in estuaries. Royal Netherlands Academy of Arts \& Sciences (KNAW), Amsterdam, p 45-61

de Deckere EMGT, Tolhurst TJ, de Brouwer JFC (2001) Destabilization of cohesive intertidal sediments by infauna. Estuar Coast Shelf Sci 53:665-669

Defew EC, Tolhurst TJ, Paterson DM (2002) Site-specific features influence sediment stability of intertidal flats. Hydrol Earth Syst Sci 6:971-981

Eckman JE, Nowell ARM, Jumars PA (1981) Sediment destabilization by animal tubes. J Mar Res 39:361-374

Flach EC (1996) The influence of the cockle, Cerastoderma edule, on the macrozoobenthic community of tidal flats in the Wadden Sea. PSZN I: Mar Ecol 17:87-98

> Flemming BW, Delafontaine MT (2000) Mass physical properties of muddy intertidal sediments: some applications, misapplications and non-applications. Cont Shelf Res 20: 1179-1197

Friedrichs M, Graf G, Springer B (2000) Skimming flow induced over a simulated polychaete tube lawn at low population densities. Mar Ecol Prog Ser 192:219-228

Gérino M, Stora G (1991) Invitro quantitative-analysis of the bioturbation induced by the polychaete Nereis-Diversicolor. C R Acad Sci Ser III Life Sci 313:489-494

Gérino M, Stora G, Francois-Carcaillet F, Gilbert F and others (2003) Macro-invertebrate functional groups in freshwater and marine sediments: a common mechanistic classification. Vie Milieu 53:221-231

> Grant J, Daborn G (1994) The effects of bioturbation on sediment transport on an intertidal mudflat. Neth J Sea Res 32: 63-72

Hentschel BT (1998) Intraspecific variations in $\delta^{13} \mathrm{C}$ indicate ontogenetic diet changes in deposit-feeding polychaetes. Ecology 79:1357-1370

Herman PMJ, Middelburg JJ, Heip CHR (2001) Benthic community structure and sediment processes on an intertidal flat: results from the ECOFLAT project. Cont Shelf Res 21: 2055-2071

Hoagland KD, Rosowski JR, Gretz MR, Roemer SC (1993)
Diatom extracellular polymeric substances: function, finestructure, chemistry, and physiology. J Phycol 29:537-566

Holland AF, Zingmark RG, Dean JM (1974) Quantitative evidence concerning the stabilization of sediments by marine benthic diatoms. Mar Biol 27:191-196

Jeffrey SW, Mantoura RFC, Wright SW (1997) Phytoplankton pigments in oceanography. United Nations International, Paris

Jones CG, Lawton JH, Shachak M (1994) Organisms as ecosystem engineers. Oikos 69:373-386

> Jumars PA, Nowell ARM (1984a) Effects of benthos on sediment transport: difficulties with functional grouping. Cont Shelf Res 3:115-130

Jumars PA, Nowell ARM (1984b) Fluid and sediment dynamic effects on marine benthic community structure. Am Zool 24:45-55

Kamermans P, van der Veer HW, Karczmarski L, Doeglas GW (1992) Competition in deposit-feeding and suspensionfeeding bivalves: experiments in controlled outdoor environments. J Exp Mar Biol Ecol 162:113-135

Kromkamp JC, Forster RM (2003) Developments in microphytobenthos primary productivity studies. In: Kromkamp JC, de Brouwer JFC, Blanchard GF, Forster RM, Creach V (eds) Functioning of microphtyobenthos in estuaries. Royal Netherlands Academy of Arts \& Sciences (KNAW), Amsterdam, p 9-30

Krumbein WE, Paterson DM, Stal LJ (1994) Biostabilization of sediments. Bibliotheks- und Informationssystem der Carl von Ossietzky Universitaet Oldenburg, Oldenburg

> Larson F, Sundbäck K (2008) Role of microphytobenthos in recovery of functions in a shallow-water sediment system after hypoxic events. Mar Ecol Prog Ser 357:1-16

Le Hir P, Monbet Y, Orvain F (2007) Sediment erodability in sediment transport modelling: Can we account for biota effects? Cont Shelf Res 27:116-1142

Mitchener H, Torfs H (1996) Erosion of sand/mud mixtures. Coast Eng 29:1-25

Murray JMH, Meadows A, Meadows PS (2002) Biogeomorphological implications of microscale interactions between sediment geotechnics and marine benthos: a review. Geomorphology 47:15-30

Norkko A, Rosenberg R, Thrush SF, Whitlatch RB (2006) Scale- and intensity-dependent disturbance determines the magnitude of opportunistic response. J Exp Mar Biol Ecol 330:195-207

- Orvain F, Sauriau PG, Sygut A, Joassard L, Le Hir P (2004) Interacting effects of Hydrobia ulvae bioturbation and microphytobenthos on the erodibility of mudflat sediments. Mar Ecol Prog Ser 278:205-223

Orvain F, Sauriau PG, Bacher U, Prineau M (2006) The influence of sediment cohesiveness on bioturbation effects due to Hydrobia ulvae on the initial erosion of intertidal sediments: a study combining flume and model approaches. J Sea Res 55:54-73

> Osakabe M, Hongo K, Funayama K, Osumi S (2006) Amensalism via webs causes unidirectional shifts of dominance in spider mite communities. Oecologia 150:496-505

Paarlberg AJ, Knaapen MAF, De Vries MB, Hulscher SJMH, Wang ZB (2005) Biological influences on morphology and bed composition of a intertidal flat. Estuar Coast Shelf Sci 64:577-590

Palomo G, Iribarne O (2000) Sediment bioturbation by polychaete feeding may promote sediment stability. Bull Mar Sci 67:249-257

Paterson DM (1989) Short-term changes in the erodibility of intertidal cohesive sediments related to the migratory behavior of epipelic diatoms. Limnol Oceanogr 34:223-234 
Rabaut M, Guilini K, Van Hoey G, Vincx M, Degraer S (2007) A bio-engineered soft-bottom environment: the impact of Lanice conchilega on the benthic species specific densities and community structure. Estuar Coast Shelf Sci 75: 525-536

Rhoads DC (1967) Biogenic reworking of intertidal and subtidal sediments in Barnstable Harbor and Buzzard Bay, Massachusetts. J Geol 75:461-476

Rhoads DC, Young DK (1970) The influence of depositfeeding organisms on sediment stability and community trophic structure. J Mar Res 28:150-178

Scoffin TP (1970) The trapping and binding of subtidal carbonate sediments by marine vegetation in Bimini Lagoon, Bahamas. J Sediment Petrol 40:249-273

Sistermans WCH, Hummel H, Engelberts A, Markusse MM (2005) Inventarisatie macrofauna Westerschelde 2004 Rapportage in het kader van de evaluatie van de verdieping van de Westerschelde, NIOO-CEME (KNAW), Yerseke

Snelgrove PVR, Butman CA (1994) Animal sediment relationships revisited: cause versus effect. Oceanogr Mar Biol Annu Rev 32:111-177

Temmerman S, Bouma TJ, Van de Koppel J, Van der Wal DD, De Vries MB, Herman PMJ (2007) Vegetation causes channel erosion in a tidal landscape. Geology 35:631-634

Tolhurst TJ, Black KS, Shayler SA, Mather S, Black I, Baker K, Paterson DM (1999) Measuring the in situ erosion shear stress of intertidal sediments with the cohesive strength meter. Estuar Coast Shelf Sci 49:281-294

Underwood AJ (1997) Experiments in ecology: their logical design and interpretation using analysis of variance. Cambridge University Press, Cambridge

Underwood GJC, Paterson DM (1993) Seasonal-changes in diatom biomass, sediment stability and biogenic stabilization in the Severn Estuary. J Mar Biol Assoc UK 73: 871-887

- Van Colen C, Montserrat F, Herman PMJ, Vincx M, Ysebaert T, Degraer S (2008) Macrobenthic recovery from hypoxia in an estuarine tidal mudflat Mar Ecol Prog Ser 372:31-42

van de Koppel J, Herman PMJ, Thoolen P, Heip CHR (2001) Do alternate stable states occur in natural ecosystems? Evidence from a tidal flat. Ecology 82:3449-3461

van de Koppel J, van der Wal D, Bakker JP, Herman PMJ (2005) Self-organisation and vegetation collapse in salt marsh ecosystems. Am Nat 165:E1-E12

van Duren LA, Herman PMJ, Sandee AJJ, Heip CHR (2006)

Editorial responsibility: Paul Snelgrove,

St. John's, Newfoundland, Canada
Effects of mussel filtering activity on boundary layer structure. J Sea Res 55:3-14

van Ledden M, van Kesteren WGM, Winterwerp JC (2004) A conceptual framework for the erosion behaviour of sandmud mixtures. Cont Shelf Res 24:1-11

van Rijn LC (1993) Principles of sediment transport in rivers, estuaries and coastal seas. Aqua Publications, Amsterdam

van Wesenbeeck BK, van de Koppel J, Herman PMJ, Bakker JP, Bouma TJ (2007) Biomechanical warfare in ecology; negative interactions between species by habitat modification. Oikos 116:742-750

Widdows J, Brinsley MD, Salkeld PN, Lucas CH (2000) Influence of biota on spatial and temporal variation in sediment erodability and material flux on a tidal flat (Westerschelde, The Netherlands). Mar Ecol Prog Ser 194:23-37

> Widdows J, Blauw A, Heip CHR, Herman PMJ and others (2004) Role of physical and biological processes in sediment dynamics of a tidal flat in Westerschelde Estuary, SW Netherlands. Mar Ecol Prog Ser 274:41-56

> Widdows J, Friend PL, Bale AJ, Brinsley M, Pope ND, Thompson CEL (2007) Inter-comparison between five devices for determining erodability of intertidal sediments. Cont Shelf Res 27:1174-1189

Winterwerp JC, van Kesteren WGM (2004) Introduction to the physics of cohesive sediment in the marine environment, Vol 56. Elsevier, Amsterdam

- Wolfstein K, de Brouwer JFC, Stal LJ (2002) Biochemical partitioning of photosynthetically fixed carbon by benthic diatoms during short-term incubations at different irradiances. Mar Ecol Prog Ser 245:21-31

Wood R, Widdows J (2002) A model of sediment transport over an intertidal transect, comparing the influences of biological and physical factors. Limnol Oceanogr 47 : 848-855

Woodin SA (1978) Refuges, disturbance, and community structure-marine soft-bottom example. Ecology 59:274-284

Woodin SA, Jackson JBC (1979) Interphyletic competition among marine benthos. Am Zool 19:1029-1043

Ysebaert T (2000) Macrozoobenthos and waterbirds in the estuarine environment: spatio-temporal patterns at different scales. Communications of the Institute of Nature Conservation, Brussels

Ysebaert T, Herman PMJ (2002) Spatial and temporal variation in benthic macrofauna and relationships with environmental variables in an estuarine, intertidal soft-sediment environment. Mar Ecol Prog Ser 244:105-124

Submitted: January 23, 2008; Accepted: October 6, 2008

Proofs received from author(s): December 3, 2008 